Journal of Counselor Practice, 11(1):85-106, 2020

DOI: $10.22229 /$ cou 1112020

Copyright (C) Ohio Counseling Association

\title{
Motivation, Perceptions, and Engagement Related to Participation in Personal Counseling Among Master's Level Counselors-in-Training in Ohio
}

\author{
Madeleine M. Stevens ${ }^{1}$ \\ Ohio University \\ Amy E. Williams \\ Youngstown State University \\ Sarah E. Dowd \\ Michigan Technological University
}

This study discusses the importance of personal counseling as a method of self-care for counselors-in-training. Researchers surveyed 157 counselors-in-training in CACREPaccredited programs in Ohio, specifically assessing beliefs, attitudes, and values of counselors-in-training regarding participating in personal counseling and participants' perceived benefits and barriers to participation in the practice. The study found that students who have a history of engaging in personal counseling have more positive perceptions of counseling. Additionally, the study found that time and finances were counseling students' top two barriers to participating in personal counseling. The researchers seek to contribute to the literature regarding counseling students' perceptions of the counseling field and their personal needs as well as enhance the counselor education field by providing data that promotes counseling students' access to counseling.

Keywords: Self-care of counselors-in-training, Self-care, Counselor education, Personal counseling, Counseling students

Counselors and counselors-in-training (CITs) are responsible for supporting the well-being and mental health of their clients, and self-care is critical in ensuring

\footnotetext{
1 Madeleine M. Stevens, Ohio University, 35 Hocking St. Apt. 201 Athens, OH 45701, ms222706@ohio.edu, 330-719-6980.
} 
quality care. Counselors and CITs are ethically obligated to do no harm to clients. It is important to explore the effects of participating in the self-care method of personal counseling, because the practice of self-care is a standard set in place by the Council for Accreditation of Counseling and Related Educational Programs (CACREP; CACREP, 2016). Among graduate counseling students, proven benefits of personal counseling include enhanced personal development and relational capacities and increased conviction in the efficacy of therapy (Orlinsky, Schofield, Schroder, \& Kazantzis, 2011). Byrne and Ost (2016) also state that personal therapy may assist CITs in their exploration of their own capacity to work with clients.

Counselor education literature suggests that educators - and in turn, studentshave a duty to demonstrate a commitment to consistently working on personal challenges in order to model effectiveness for students and clients (Lawson, et al., 2007). Also, the counseling profession and the settings in which future counselors train should promote a culture of wellness (Lawson, et al., 2007). However, the literature notes that CITs and mental health professionals alike may decline to pursue personal counseling for a multitude of reasons, including a lack of perceived value of personal counseling, confidentiality concerns, financial reasons, fear of exposure, time constraints, and difficulty finding a skilled therapist (Byrne \& Shufelt, 2014; Norcross et al., 2008). Because of the differing results presented in the literature and the lack of evidence pertaining to counseling students in particular, more research is needed to determine why CITs abstain from personal counseling and what would promote their utilization of the service. 


\section{The Role of Self-Care in Counseling}

Best practices in counseling require that counselors care for themselves in order to provide care to their clients. Lawson, Venart, Hazler, and Kottler (2007) explain:

...The counseling profession is more than theory, techniques, brilliant thoughts, and words produced in a tastefully decorated office. It is a complex human experience in which well-trained individuals must learn to care for themselves as well as clients, family, and society if they expect continuing success as professionals and as human beings. (p. 8)

Often referred to as self-care, the practice varies among professionals, with a common theme of personal wellness uniting a diverse range of practices. Common forms of self-care include meditation, mindfulness, exercise, and creative expression such as music and art (Matorell-Poveda, Martinez-Hernáez, Carceller-Maicas, \& Correa-Urquiza, 2015; Schwan, Fallon, \& Milne, 2018). The American Counseling Association (ACA) Code of Ethics (2014) requires counselors to engage in self-care activities in order to maintain and promote their own wellness in order to best meet their professional responsibilities and provide effective care to clients. These ethical requirements also apply to CITs.

The practice of self-care is a standard set in place by the Council for Accreditation of Counseling and Related Educational Programs (CACREP; CACREP, 2016). Self-care is also an expectation of educational training curricula for programs accredited by CACREP, and counselor educators are responsible for demonstrating a commitment to working on personal challenges in order to model ethical and personal responsibilities for 
addressing mental health concerns for students in their charge (Lawson et al., 2007). Thus, it is counselor educators' responsibility to consider their students' mental health and wellness and to discuss self-care throughout training (Prosek, Holm, \& Daly, 2013; CACREP, 2016).

\section{Common Issues Experienced by Counselors-in-Training}

Research shows that individuals working within the helping professions experience burnout (O'Halloran \& Linton, 2000; Maslach, 2003; Newsome, Chambers Christopher, Dahlen, \& Christopher, 2006; Thompson, Amatea, \& Thompson, 2014), which is a term first used by Freudenberger (1974) to describe helping professionals who become exhausted due to excessive demands on their energy and resources. Helping professionals may also experience compassion fatigue and vicarious traumatization (Baker, 2003). Mental and emotional impairment for counselors-in-training may result if these stressors are ignored, dismissed, or minimized (Lawson et al., 2007).

Additionally, some counselors-in-training may pursue a career as a helping professional with a history of their own emotional wounds. Carl Jung conceptualized wounded healers as those who have been wounded but who have also gone through the process of recovery and healing (Streeter, 2017; Zerubavel \& O’Dougherty Wright, 2012). These counselors may have an enhanced sense of empathy and vulnerability with clients that could aid the therapeutic relationship, having gone through the healing process themselves (Zerubavel \& O’Dougherty Wright, 2012). However, counselors who still suffer from their wounds may experience personal distress that adversely impacts their 
clinical work. Gelso and Hayes (2001) discuss the risk of impaired counselors projecting their own vulnerabilities on their clients, thus compromising counseling.

Due to the likelihood that CITs may experience these stressors during their work with clients, it is important that time is reserved by each individual to practice self-care and actively work toward wellness throughout the course of graduate study. Byrne and Ost (2016) cite the effectiveness of personal counseling in supporting CITs' self-care and increased capacity to work with clients.

\section{Counselors-in-Training in Personal Counseling}

Training programs provide a prime opportunity for counselor educators to instill self-care practices in their students, including the use of personal counseling. Among graduate counseling students, proven benefits of personal counseling include enhanced personal development and relational capacities and increased conviction in the efficacy of therapy (Orlinsky, Schofield, Schroder, \& Kazantzis, 2011). Personal counseling may also provide CITs with an opportunity to explore and understand their motivations to become counselors as well as promote professional development (Byrne \& Ost, 2016). Some training programs have mandated that students participate in personal counseling. Research has discovered that students enrolled in counseling programs that require personal counseling reported higher levels of perceived social support and lower levels of distress (Leech, 2007). Another study conducted by Prosek, Holm, and Daly (2013) adds support to the idea that required personal counseling for counselors-in-training may reduce personal distress; specifically, the authors found decreases in symptoms of depression and 
anxiety as well as a reduction in overall problems reported by the participants who participated in personal counseling. Prosek, Holm, and Daly's (2013) study adds to the current literature surrounding graduate students' participation in personal counseling. However, the aforementioned studies used a small, non-diverse sample, which limits generalizability of their findings.

Though personal counseling has been shown to be an effective form of self-care for students enrolled in counselor training programs, CITs may choose to abstain from engaging in personal counseling for various reasons. Byrne and Shufelt (2014) note that CITs may decline to pursue personal counseling due to a lack of perceived value of personal counseling in promoting personal development. Further research illuminates professionals' perceptions that they receive sufficient support from personal relationships and that they cope effectively with challenges (Byrne \& Ost, 2016; Norcross, Bike, Evans, \& Schatz, 2008). In short, CITs may feel that they already have adequate self-care practices and social supports in place, and therefore, personal counseling is perceived as unnecessary.

The study seeks to add to the limited body of research regarding master's-level CITs' utilization of counseling services and explore participants' attitudes toward personal counseling. The current study measured frequencies reported by master's level CITs related to participation in personal counseling; assessed beliefs, attitudes and values of CITS regarding participating in personal counseling; examined participants' perceived benefits and barriers to participation in personal counseling; and explored potential differences in attitudes surrounding personal counseling based upon whether participants had previous experience in personal counseling. Researchers hypothesized that there would be a statistically significant difference between the attitudes and beliefs regarding 
personal counseling among participants who have and have not participated in personal counseling as measured by a researcher-created instrument embedded within the overall study survey.

\section{Methods}

This quantitative survey-design study was conducted in the Summer of 2018. Surveys were administered via email to master's-level students in counselor education programs in Ohio that are accredited by the CACREP. The survey collected information regarding participants' attitudes toward counseling and their feelings about engaging in personal counseling. It also gathered data related to participant engagement in personal counseling, reasons for and deterrents to participation in personal counseling, program requirements and recommendations related to personal counseling, and demographic data.

\section{Participants}

Participants were volunteers from CACREP-accredited graduate programs in counseling within the state of Ohio. All participants were at least 18 years old and were enrolled either part-time or full-time in a degree-seeking or non-degree seeking counselor training program. A total of 157 participants completed the survey. Of these, 155 provided demographic information for analysis. Approximately $81 \%$ of participants were female $(n=126)$ and $19 \%$ were male $(n=29)$. Tables 1 through 4 present demographic data related to age, racial identity, ethnic identity, and relationship status, respectively. 
Table 1

Participant Age

\begin{tabular}{|l|l|l|}
\hline Age Band & $\boldsymbol{n}$ & Percent of Total \\
\hline $21-25$ & 75 & $48.39 \%$ \\
\hline $26-30$ & 37 & $23.87 \%$ \\
\hline $31-35$ & 17 & $10.97 \%$ \\
\hline $36-40$ & 14 & $9.03 \%$ \\
\hline $41-45$ & 7 & $4.52 \%$ \\
\hline 46 or older & 3 & $1.94 \%$ \\
\hline no response & 2 & $1.29 \%$ \\
\hline
\end{tabular}

Table 2

\section{Participant Race}

\begin{tabular}{|l|l|l|}
\hline Race & $\boldsymbol{n}$ & Percent of Total \\
\hline African-American & 8 & $5.16 \%$ \\
\hline Other (American Indian, Alaska Native, Asian) & 3 & $1.94 \%$ \\
\hline Caucasian & 136 & $87.74 \%$ \\
\hline Two or more races & 8 & $5.16 \%$ \\
\hline & & \\
\hline
\end{tabular}

Table 3

Participant Ethnicity

\begin{tabular}{|l|l|l|}
\hline Ethnicity & $\boldsymbol{n}$ & Percent of Total \\
\hline Hispanic/Latino & 10 & $6.45 \%$ \\
\hline Non-Hispanic/Non-Latino & 145 & $93.55 \%$ \\
\hline
\end{tabular}

Table 4

Relationship Status

\begin{tabular}{|l|l|l|}
\hline Relationship Status & $\boldsymbol{n}$ & Percent of Total \\
\hline Dating & 50 & $32.26 \%$ \\
\hline
\end{tabular}




\begin{tabular}{|l|l|l|}
\hline Married & 35 & $22.58 \%$ \\
\hline Separated/divorced & 8 & $5.16 \%$ \\
\hline Single & 57 & $36.77 \%$ \\
\hline Other & 5 & $3.23 \%$ \\
\hline
\end{tabular}

Approximately $70 \%$ of participants were enrolled at public institutions $(n=108)$ and $30 \%$ were enrolled in private institutions $(n=47)$. Approximately $95 \%$ of participants reported their program did not require counseling $(n=148)$ while approximately 5\% reported that their program did require it $(n=7)$. Among those participants whose programs that did not require personal counseling, approximately $86 \%$ of participants reported their programs recommended personal counseling $(n=127)$, while $14 \%$ reported their programs did not make this recommendation $(n=21)$. Survey data reflecting program track, participant progress in the program at the time of survey completion and prior level of education are provided in table 4 through 6 , respectively.

Table 4

\section{Program Track}

\begin{tabular}{|l|l|l|}
\hline Program Track & $\boldsymbol{n}$ & Percent of Total \\
\hline Addiction Counseling & 2 & $1.29 \%$ \\
\hline Clinical Mental Health Counseling & 92 & $59.35 \%$ \\
\hline College Counseling and Student Affairs & 4 & $2.58 \%$ \\
\hline Marriage, Couple, and Family Counseling & 6 & $3.87 \%$ \\
\hline School Counseling & 20 & $12.90 \%$ \\
\hline Multiple Tracks & 30 & $19.35 \%$ \\
\hline Other & 1 & $0.65 \%$ \\
\hline
\end{tabular}

\section{Table 5}

Progress in Program

\begin{tabular}{|l|l|l|}
\hline Progress in Program & $\boldsymbol{n}$ & Percent of Total \\
\hline Currently completing internship & 36 & $23.23 \%$ \\
\hline
\end{tabular}




\begin{tabular}{|l|l|l|}
\hline Currently completing practicum & 27 & $17.42 \%$ \\
\hline Not currently enrolled in practicum or internship & 89 & $57.42 \%$ \\
\hline Other & 3 & $1.94 \%$ \\
\hline
\end{tabular}

Table 6

Prior Educational Attainment

\begin{tabular}{|l|l|l|}
\hline Prior Educational Attainment & $\boldsymbol{n}$ & Percent of Total \\
\hline Bachelor's & 132 & $85.16 \%$ \\
\hline Master's & 19 & $12.26 \%$ \\
\hline Post-bachelor's coursework & 4 & $2.58 \%$ \\
\hline
\end{tabular}

\section{Procedure}

A pilot survey was conducted to ensure the final survey sent to study participants had adequate reliability and validity relative to the variables under study. Specifically, the pool of items focused on participants' beliefs, attitudes, and values related to personal counseling were reduced using an iterative process of computing overall reliability and ifitem-removed reliability, removing the single item that improved reliability most substantially, then repeating this process until researchers achieved a final total of 10 items and a scale reliability for these items of $r=.90$. For this, 31 students currently enrolled in a single midwestern CACREP-accredited graduate program in counseling were asked to complete the survey. These data were analyzed only to ensure adequacy of psychometric properties of this specific survey subscale and not to make inferences or draw conclusions about the data obtained relative to the focus of this study. These students were also excluded from participation in the study itself, as they were previously exposed to survey 
items and could have been influenced during a second completion of the survey. No identifying information was collected during the survey pilot.

The final study survey was distributed via email to faculty and/or staff within each program with a request to forward on to their students. Email addresses for faculty/staff members were gathered from their respective program's websites. The email included an invitation to participate in the study as well as a link to the survey, hosted by Qualtrics. Upon clicking the included link, the participant was immediately directed to the informed consent page. If the participant agreed to participate and indicated as much by clicking 'agree' on the informed consent page, the survey was presented on the next screen. If the participant chose to forego participation the survey after reading the informed consent page, they indicated as much by clicking 'disagree' and were taken to the end screen for the survey. The end screen appeared for all participants, regardless of participation in the survey. It provided information about how to utilize PsychologyToday.com to seek mental health services in his/her area.

The survey collected the participant's demographic data as well as information on his/her attitudes and beliefs about mental health counseling. Specifically, participants were asked to rate their agreement or disagreement with statements related to counseling and how they believe participation in counseling may or may not impact their lives. Demographic information relevant to the present study was also collected at the end of the survey.

\section{Results}


Survey data were analyzed first using descriptive statistics to describe overall data reported by participants for survey items. Tables 7 and 8 summarize descriptive data related to participation in personal counseling for the overall sample $(N=157)$.

\section{Table 7}

Prior Participation in Personal Counseling

\begin{tabular}{|l|l|l|}
\hline Prior Participation in Personal Counseling & $\boldsymbol{n}$ & Percent of Total \\
\hline No & 37 & $23.57 \%$ \\
\hline Yes & 120 & $76.43 \%$ \\
\hline
\end{tabular}

Table 8

Current Participation in Personal Counseling

\begin{tabular}{|l|l|l|}
\hline Current Participation in Personal Counseling & $\boldsymbol{n}$ & Percent of Total \\
\hline No & 112 & $71.34 \%$ \\
\hline Yes & 45 & $28.66 \%$ \\
\hline
\end{tabular}

Participant responses to items focusing on reasons for previous participation in personal counseling for those endorsing previous personal counseling and barriers to personal counseling for all participants are provided in tables 9 and 10, respectively. Participants were able to select more than one response for each of these items and are reported as aggregate data for the overall sample, with percentages reflecting the percent of total participants endorsing the item.

Table 9

Reasons for Participating in Personal Counseling

\begin{tabular}{|l|l|l|}
\hline Reason & Frequency & $\begin{array}{l}\text { Percent of } \boldsymbol{N} \\
(\boldsymbol{N = 1 2 6})\end{array}$ \\
\hline academic coursework & 30 & $23.81 \%$ \\
\hline family concerns & 79 & $62.70 \%$ \\
\hline
\end{tabular}




\begin{tabular}{|l|l|l|}
\hline intimate relationships & 75 & $59.52 \%$ \\
\hline friendships & 39 & $30.95 \%$ \\
\hline career concerns & 47 & $37.30 \%$ \\
\hline financial stress & 30 & $23.81 \%$ \\
\hline substance use & 13 & $10.32 \%$ \\
\hline significant MH diagnosis (as defined by the participant) & 17 & $13.49 \%$ \\
\hline feeling sad, lost, hopeless & 78 & $61.90 \%$ \\
\hline feeling on-edge and worried & 76 & $60.32 \%$ \\
\hline suicidal ideation & 33 & $26.19 \%$ \\
\hline homicidal ideation & 0 & $0.00 \%$ \\
\hline $\begin{array}{l}\text { other (e.g., self-esteem, trauma, grief, anxiety, depression, self- } \\
\text { harm, process addiction) }\end{array}$ & 15 & $11.90 \%$ \\
\hline
\end{tabular}

Table 10

Barriers to Participation in Personal Counseling

\begin{tabular}{|l|l|l|}
\hline Barriers & Frequency & $\begin{array}{l}\text { Percent of } \boldsymbol{N} \\
(\mathbf{N}=139)\end{array}$ \\
\hline Time & 113 & $81.29 \%$ \\
\hline Finances & 96 & $69.06 \%$ \\
\hline transportation & 4 & $2.88 \%$ \\
\hline confidentiality & 9 & $6.47 \%$ \\
\hline access to resources in my area & 23 & $16.55 \%$ \\
\hline fear of change & 9 & $6.47 \%$ \\
\hline fear of comfortability (as defined by the participant) & 15 & $10.79 \%$ \\
\hline previous negative experiences in counseling & 26 & $18.71 \%$ \\
\hline fit and comfortability in therapeutic relationship & 48 & $34.53 \%$ \\
\hline $\begin{array}{l}\text { other (e.g., desire for faith-based counseling, difficulty locating } \\
\text { provider who accepts specific insurance, fear, lack of cultural } \\
\text { competence in counselors, full time work, not wanting a diagnosis, } \\
\text { lack of minority counselors, lack of confidence in } \\
\text { counselors/counseling process, desire to address concerns without } \\
\text { counseling) }\end{array}$ & & \\
\hline
\end{tabular}

As described previously, a sub-scale focusing on values, attitudes, and beliefs surrounding personal counseling and related behaviors was developed and presented to participants within the survey. This subscale used a four-point Likert scale (disagree, somewhat disagree, somewhat agree, agree) to assess participant perceptions related to 
these items. Overall reliability for the final instrument based upon data collected during full data collection was $r=.680(\mathrm{~N}=157)$. Table 11 presents the items, frequency counts, and percentages for each of these items.

\section{Table 11}

Attitudes, Values, and Beliefs Scale Overall Responses

\begin{tabular}{|c|c|c|c|c|c|c|c|c|}
\hline Item & $\begin{array}{l}\text { Disagre } \\
\text { e }\end{array}$ & $\begin{array}{l}\text { Disagre } \\
\text { e } \\
\text { Percent } \\
\text { of Total }\end{array}$ & $\begin{array}{l}\text { Some- } \\
\text { what } \\
\text { Disagre } \\
\text { e }\end{array}$ & $\begin{array}{l}\text { Some- } \\
\text { what } \\
\text { Disagre } \\
\text { e } \\
\text { Percent } \\
\text { of Total }\end{array}$ & $\begin{array}{l}\text { Some } \\
\text {-what } \\
\text { Agree }\end{array}$ & $\begin{array}{l}\text { Some- } \\
\text { what } \\
\text { Agree } \\
\text { Percen } \\
\text { t of } \\
\text { Total }\end{array}$ & Agree & $\begin{array}{l}\text { Agree } \\
\text { Percen } \\
\text { t of } \\
\text { Total }\end{array}$ \\
\hline $\begin{array}{l}\text { I am confident that } \\
\text { counseling can help } \\
\text { people. }\end{array}$ & 0 & $0.00 \%$ & 0 & $0.00 \%$ & 10 & $6.37 \%$ & 147 & $\begin{array}{l}93.63 \\
\%\end{array}$ \\
\hline $\begin{array}{l}\text { Counseling can } \\
\text { serve as an aspect of } \\
\text { self-care. }\end{array}$ & 0 & $0.00 \%$ & 1 & $0.64 \%$ & 12 & $7.64 \%$ & 144 & $\begin{array}{l}91.72 \\
\%\end{array}$ \\
\hline $\begin{array}{l}\text { Seeking support } \\
\text { from others is } \\
\text { important. }\end{array}$ & 0 & $0.00 \%$ & 0 & $0.00 \%$ & 7 & $4.46 \%$ & 150 & $\begin{array}{l}95.54 \\
\%\end{array}$ \\
\hline $\begin{array}{l}\text { Counseling is only } \\
\text { for people who have } \\
\text { serious issues. }\end{array}$ & 133 & $84.71 \%$ & 22 & $14.01 \%$ & 2 & $1.27 \%$ & 0 & $0.00 \%$ \\
\hline $\begin{array}{l}\text { I believe my } \\
\text { counseling } \\
\text { education has given } \\
\text { me the tools to help } \\
\text { myself in my life's } \\
\text { issues. }\end{array}$ & 2 & $1.27 \%$ & 9 & $5.73 \%$ & 71 & $\begin{array}{l}45.22 \\
\%\end{array}$ & 75 & $\begin{array}{l}47.77 \\
\%\end{array}$ \\
\hline $\begin{array}{l}\text { Vulnerability is } \\
\text { important. }\end{array}$ & 1 & $0.64 \%$ & 5 & $3.18 \%$ & 59 & $\begin{array}{l}37.58 \\
\%\end{array}$ & 92 & $\begin{array}{l}58.60 \\
\%\end{array}$ \\
\hline $\begin{array}{l}\text { A counselor could } \\
\text { help me enhance } \\
\text { my life. }\end{array}$ & 0 & $0.00 \%$ & 3 & $1.91 \%$ & 43 & $\begin{array}{l}27.39 \\
\%\end{array}$ & 111 & $\begin{array}{l}70.70 \\
\%\end{array}$ \\
\hline $\begin{array}{l}\text { I believe counseling } \\
\text { could help me work } \\
\text { through my } \\
\text { personal issues. }\end{array}$ & 0 & $0.00 \%$ & 2 & $1.27 \%$ & 27 & $\begin{array}{l}17.20 \\
\%\end{array}$ & 128 & $\begin{array}{l}81.53 \\
\%\end{array}$ \\
\hline $\begin{array}{l}\text { There are } \\
\text { counselors who } \\
\text { could help me in my } \\
\text { life. }\end{array}$ & 0 & $0.00 \%$ & 6 & $3.82 \%$ & 20 & $\begin{array}{l}12.74 \\
\%\end{array}$ & 131 & $\begin{array}{l}83.44 \\
\% \\
\end{array}$ \\
\hline $\begin{array}{lr}\text { Engaging } & \text { in } \\
\text { counseling } & \text { would } \\
\text { make me a better } \\
\text { counselor. }\end{array}$ & 0 & $0.00 \%$ & 1 & $0.64 \%$ & 21 & $\begin{array}{l}13.38 \\
\%\end{array}$ & 135 & $\begin{array}{l}85.99 \\
\%\end{array}$ \\
\hline
\end{tabular}


Chi square tests of significance were conducted to determine whether there were statistically significant differences between subgroups in terms of engagement in personal counseling based upon the demographic data reported by participants and the adequacy of subgroup samples to conduct such analyses. Specifically, chi square tests were computed for sex (male; female) and lifetime counseling status (yes; no); age bands (21-25; 26-30; 31-35; 36-40; and 41 and older) and lifetime counseling status (yes; no); and current relationship status (dating; married; separated/divorced; single; other) and lifetime counseling status (yes; no). None of these chi square tests yielded statistically significant results, meaning there were no statistically significant differences in lifetime participation in personal counseling based upon subgroup characteristics for the demographic categories analyzed. Chi square tests were not conducted for race and ethnicity due to limited subgroup representation within the sample.

An independent samples $t$-test was computed to determine statistical significance between overall score on the beliefs, attitudes, and values sub-scale for participants who reported previous participation in personal counseling versus those who reported not participating in personal counseling. Overall scores were computed by summing item scores for each participant, with disagree equal to 1 point, somewhat disagree equal to 2 points, somewhat agree equal to 3 points, and agree equal to 4 points. For the fourth item in this subscale (counseling is only for people who have serious issues), reverse scoring was used, and scores were adjusted accordingly prior to analysis. 
There was a statistically significant difference in scores on the attitudes, values, and beliefs subscale between participants who had $(M=36.16 ; S D=2.67)$ and had not $(M=38.11$; $S D=1.95)$ ever participated in personal counseling, $t(40)=-3.89, p<.001, d=.83$. Levene's test was statistically significant $(F=5.64, p=.019)$, so degrees of freedom were adjusted from 155 to 40 . Overall scores on this subscale were greater and standard deviation smaller for the group who reported lifetime participation in counseling, indicating that participants who participated in personal counseling rated the subscale items approximately 2 points higher overall than the participants who had not ever participated in counseling. The effect size for this difference is large.

\section{Discussion}

The first notable finding in this study is the use of personal counseling by CITs. Approximately 76 percent of participants in this survey have engaged in personal counseling, while only an approximate 29 percent were currently engaged in the practice at the time of the survey. Participants reported that their main reasons for seeking counseling include family concerns (62.70\%); feeling sad, lost, hopeless (61.90\%); feeling on-edge, worried $(60.32 \%)$; and intimate relationships $(59.52 \%)$. These concerns imitate the presenting concerns of most clients who pursue counseling and should not be taken lightly. The data revealed that lack of time and financial hardship were the CITs' two most significant barriers to engaging in personal counseling. However, the general perception of counseling is positive, and the practice is believed to be beneficial for personal and professional reasons. 
Most participants in the survey believe counseling is helpful and can serve as a form of self-care. They also believe seeking support is important, and vulnerability is valued. The data shows that CITs believe counseling is not only for those individuals experiencing severe issues, and counseling would be beneficial to their personal growth and professional performance as counselors. It should be noted that participants believe their counseling education has given them tools to help themselves should they experience personal issues.

The results of the independent samples t-test shed light on another interesting aspect of the data. Those participants who have participated in personal counseling regard the practice as more helpful than those who have not participated in personal counseling. In other words, those CITs who have had the experience of being clients reported more positive perceptions of engaging in counseling.

The results of this research provide several important implications for the counseling profession as a whole. Particularly, the data suggests that engagement in counseling increases CITs' positive perceptions of counseling and most students surveyed believe counseling is valuable, regardless of their personal history of engaging in counseling. However, only 5 percent of counseling programs in the study require CITs to engage in personal counseling but 86 percent recommend it. Because the effects of CITs' engaging in personal counseling results in more positive perceptions of counseling, but CITs refrain from participating in the practice because of time and finances, the researchers beg the question: How can counselor education programs better support CITs in engaging in personal counseling and reduce barriers to their participation?

More data is needed to provide evidence-based practices that counselor education programs can use to support CITs' participation in counseling. However, the researchers 
have conceptualized several suggestions based on this research study. Counselor training programs could work with local mental health agencies or private practices to provide a number of reduced-fee or free counseling sessions to CITs. Additionally, counselor education faculty could discuss the literature surrounding the benefits of CITs engaging in personal counseling and promote class discussion about how personal counseling may help students. Following the discussion, faculty could provide contact information of local mental health organizations. Counselor education programs could also develop attendance policies that allow students absences from class in order to attend personal counseling sessions.

\section{Areas of Future Research}

The current study only focused on CITs in CACREP-accredited programs in the state of Ohio. While the data may be generalizable to the general CIT population in this state, it may not me generalizable to the CIT population nationally or internationally. More expansive research is needed to understand the wider population's motivations, engagement, and perceptions of CITs engaging in personal counseling. Additionally, this study's participants were mostly Caucasian and identified as female. Expanding the study to a larger population of participants may increase the diversity of responses, and therefore may change the chi square test results. Including students at the $\mathrm{PhD}$ level rather than only master's students would also alter the data.

Another possible area of future research is to survey CITs in non-CACREPaccredited programs in order to compare the motivations, engagement, and perceptions of 
personal counseling between the groups. This would allow counselor educators to better understand this student population. Additionally, examining the difference in beliefs and behaviors of those CITs in programs that require counseling versus those that do not would help educators understand how the requirement may affect students.

Finally, an examination of the messages received by CITs from their educators and supervisors may provide insight into how CITs are learning to feel about their clients and the field itself. This could be done by expanding the study to examine the impact of counselor educators' messages to their students about their own experiences engaging in personal counseling. A study that examines the impact of counselor educators' perceptions of their clients and how those messages may affect students' attitudes toward engaging in counseling would also be helpful. 


\section{References}

Baker, E.K. (2003). Caring for ourselves: A therapist's guide to personal and professional well-being. Washington, DC: American Psychological Association.

Byrne, J.S. \& Ost, A.R. (2016). Personal counseling factors among counseling trainees: Results from a nationwide survey. Ideas and Research You Can Use: VISTAS 2016, 2.

Byrne, J.S. \& Shufelt, B. (2014). Factors for personal counseling among counseling trainees. Counselor Education \& Supervision, 53(3), 178-189.

Council for Accreditation of Counseling and Related Educational Programs. (2016). 2016 CACREP Standards: Professional Counseling Identity. Retrieved from http://www.cacrep.org/section-2-professional-counseling-identity/

Freudenberger, H.J. (1974). Staff Burn-Out. Journal of Social Issues, 30(1), 159-165. https://doi-org.proxy.library.ohio.edu/10.1111/j.1540-4560.1974.tb00706.x

Gelso, C.J., \& Hayes, J.A. (2007). Countertransference and the therapist's inner experience: Perils and possibilities. Mahwah, NJ: Erlbaum.

Kastberg, S.M., Jordan, R. A., Kiweewa, J.M. \& Clingerman, T. (2014). Counselor as client: Emerging answers and new questions. The Practitioner Scholar: Journal of Counseling and Professional Psychology, 3(2).

Lawson, G., Venart, E., Hazler, R.J. \& Kottler, J.A. (2007). Toward a culture of counselor wellness. Journal of Humanistic Counseling, Education and Development, 46(5), 8-9. 
Leech, N.L. (2007). Requiring counseling in master's-level counseling programs:

Students' perceptions of counseling and psychological characteristics. Research in the Schools, 14(1).

Maslach, C. (2003). Job burnout: New directions in research and intervention. Current Directions in Psychological Science, 12, 189-192.

Matorell-Poveda, M.A., Martinez-Hernáez, A., Carceller-Maicas, N., Correa-Urquiza, M. (2015). Self-care strategies for emotional distress among young adults in Catalonia: A qualitative study. International Journal of Mental Health Systems, $9(9), 1-11$

Newsome, S., Chambers Christopher, J., Dahlen, P, \& Christopher, S. (2006). Teaching counselors self-care through mindfulness practices. Teachers College Record, 108(9), 1881-1900.

Norcross, J.C., Bike, D.H., Evans, K L. \& Schatz, D.M. (2008). Psychotherapists who abstain from personal therapy: Do they practice what they preach? Journal of Clinical Psychology, 64(12), 1372.

O’Halloran, T.M., \& Linton, J.M. (2000). Stress on the Job: Self-Care Resources for Counselors. Journal of Mental Health Counseling, 22(4), 354. Retrieved from https://search-ebscohostcom.proxy.library.ohio.edu/login.aspx?direct=true\&db=aph\&AN=3701454\&site= ehost-live \&scope=site

Orlinsky, D.E., Schofield, M.J., Schroder, T. \& Kazantzis, N. (2011). Utilizing personal therapy by psychotherapists: A practice-friendly review and a new study. Journal of Clinical Psychology: In Session, 67(8), 828-829. 
Prosek, E.A., Holm, J.M. \& Daly, C.M. (2013). Benefits of required counseling for counseling students. Counselor Education \& Supervision, 52, 243-244.

Schwan, K.J., Fallon, B., \& Milne, B. (2018). "The one thing that actually helps": Art creation as a self-care and health-promoting practice amongst youth experiencing homelessness. Children and Youth Services Review, 93, 355-364.

Streeter, A.M. (2017). The Wounded Healer: Lived experiences of self-identified wounded counselors. (Doctoral dissertation). Retrieved from ProQuest. (10619629)

Thompson, I.A., Amatea, E.S., \& Thompson, E.S. (2014). Personal and contextual predictors of mental health counselors' compassion fatigue and burnout. Journal of Mental Health Counseling, 36(1), 58-77.

Zerubavel, N. \& O'Dougherty Wright, M. (2012). The dilemma of the wounded healer. Psychotherapy Theory Research Practice Training, 49(4), 482-491. 